\title{
PSYCHOLOGY
}

\section{ПСИХОЛОГІЧНІ ОСОБЛИВОСТІ ПРОЯВУ РЕВНОЩІВ ЯК ФЕНОМЕНУ ПОДРУЖНЬОГО ЖИТТЯ У СТУДЕНТСЬКИХ СІМ'ЯХ}

\author{
${ }^{1}$ к. психол. н., дочент Антонова 3. О. \\ ${ }^{2}$ к. психол. н., доцент Левицька Т. Л. \\ ${ }^{3}$ аспірант кафедри психології та педагогіки Петяк О. В. \\ ${ }^{I}$ Украӥна, м. Хмельницький, Хмельницький національний університет, доцент кафедри \\ психології та педагогіки. \\ ${ }^{2}$ Україна, м. Хмельницький, Хмельницький національний університет, дочент кафедри \\ психології та педагогіки. \\ ${ }^{3}$ Україна, м. Хмельницький, Хмельницький наџіональний університет, аспірант.
}

DOI: https://doi.org/10.31435/rsglobal_wos/31012019/6320

\section{ARTICLE INFO}

Received: 28 November 2018

Accepted: 17 January 2019

Published: 31 January 2019

\section{KEYWORDS}

family,

jealousy,

representation of marital jealousy,

betrayal,

sexual partner,

infidelity.

\begin{abstract}
Jealousy is one of the strongest, destructive and painful emotions. They are most often accompanied by any personal relationship between a person, whether intimate, business or family. Thus, jealousy is one of those aspects of human life that does not change over time. Relationships in which jealousy harms both personality and the psychological climate of society.

The article actualizes the problem of studying the psychology of family and marital revenge. The results of empirical research of psychological peculiarities of the ideas of marital jealousy of students of higher educational institutions are presented. Almost every couple, sooner or later, regardless of the length of the relationship, faces the jealousy of the partner or the thought of a possible betrayal. The study analyzed what constitutes a problem of jealousy, how jealousy manifests itself in family relationships and what consequences can lead to it.
\end{abstract}

Citation: Антонова 3. О., Левицька Т. Л., Петяк О. В. (2019) Psykholohichni Osoblyvosti Proiavu Revnoshchiv yak Fenomenu Podruzhnoho Zhyttia u Studentskykh Simiakh. International Academy Journal Web of Scholar. 1(31), Vol.2. doi: 10.31435/rsglobal_wos/31012019/6320

Copyright: (C) 2019 Антонова 3. О., Левицька Т. Л., Петяк О. В. This is an open-access article distributed under the terms of the Creative Commons Attribution License (CC BY). The use, distribution or reproduction in other forums is permitted, provided the original author(s) or licensor are credited and that the original publication in this journal is cited, in accordance with accepted academic practice. No use, distribution or reproduction is permitted which does not comply with these terms.

Вступ. Ревнощі - одна 3 найбільш сильних, згубних і хворобливих емоцій. Вони викликають стрес, почуття страху, страждання, нервові розлади, провокують іншу людину на брехню, помсту, зраду. Життя, отруєне надмірними ревнощами, стає нестерпним для всієї сім'ї. Воно псує фізичне та психічне здоров'я, відображається на вихованні дітей. Найнебезпечніші наслідки показує кримінальна статистика: в Україні серед побутових злочинів мотив ревнощів стає їх причиною в майже $55 \%$.

Психологія сім'ї є однією зі значних предметних областей вивчення особистості і суб'єкта діяльності. Особистість формується і розвивається в просторі сім'ї, в зв'язку з чим, проблема внутрішньосімейної взаємодії трансформується в психолого-педагогічний феномен, потреба у вивченні якого проявляється не тільки в соціальній психології, в психології особистості, а й у педагогічній психології. Практика показує, що сімейні стосунки реалізуються в різних формах, в їх числі на перший погляд негативні прояви ревнощів членів подружжя. Однак ревнощі як об'єкт психологічного дослідження може служити джерелом виявлення не 
тільки негативістських тенденцій у сімейних відносинах, а й джерелом формування позитивного досвіду у майбутнього подружжя. Проблема уявлень про ревнощі як детермінанта подружніх відносин знаходиться на стику декількох напрямків дослідних пошуків психологічної науки. Подружні відносини зазнали в останні роки суттєвої наукової розробки. На сьогодні вивчені питання дошлюбних відносин (Бурлачук Л.Ф., Коростильова Л.А., Шнейдер Л.Б., Сатир В. та ін.), позначені фактори (Ейдеміллер Е.Г., Юстицкис В.В., Юркович Н.А., Файнбург 3.) і механізми (Голод І.С., Обозов М.М., Харчев А.Г., Сатир В., Уайл Г.) побудови шлюбу, виділені різноманітні типи функціонування подружніх відносин (Андрух Г.П., Кратохвил С., Кришталь В.В., Сейгер Л., Шнейдер Л.Б.), встановлені психологічні причини їх порушення (Обозов Н.Н., Обозова О.М.) і т. д. У проблемному полі психології шлюбу позначені також деякі підходи до розгляду подружніх ревнощів (Васильєва О.С., Куттер П., Лінчевський Е.Е., Терентьєв С.І.). Разом з тим, залишаються нез'ясованими питання, які ж існують психологічні передумови функціонування ревнощів в подружніх стосунках. Зокрема, залишається не ясною роль уявлень про ревнощі у виникненні відповідного феномена в подружніх стосунках.

3 іншого боку, в роботах сучасних авторів (Гудова Н.В., Жубаркін С.В., Левченко А.В., Мацук М.А.) розкрита роль психологічних уявлень в побудові життєдіяльності людини. У ряді досліджень вивчені особливості уявлень про деякі аспекти сімейних і подружніх відносин. Так, А.М. Прихожан вивчені уявлення підлітків i юнаків про своє майбутнє сімейне життя. Н.Г. Аристовою показана значимість уявлень молоді дошлюбного віку про сексуальні стосунки i їх наслідки. Л.С. Алексєєвою розкрита роль уявлень про партнера в розвитку відносин подружжя. У цьому контексті інтерес викликає вивчення особливостей уявлень про ревнощі як детермінанту подружніх відносин. Виходячи 3 цього, ми визначили мету нашого дослідження - вивчити психологічні особливості уявлень студентів про подружні ревнощів. Отже, значення феномену ревнощів у подружніх стосунках, у тому числі патологічних, зараз особливо зростає, оскільки вони виявляються тісно пов'язаними 3 проблемою особистості й людського фактора.

Результати дослідження. Історія виникнення поняття «ревнощі» походить із давнини. Їх розглядали як один із видів емоційного стану людини, наприклад як «вид страху при бажанні зберегти за собою володіння якимось благом». Ревнощі пов'язували 3 такими емоціями, як образа самоповаги, гнів, прагнення до повного панування, сумнів, самодокір, страждання, тривога. Деякі вчені об'єднували ревнощі 3 почуттям заздрощів. У тлумачному словнику В. І. Даля цим словом позначається сліпа й пристрасна недовіра, сумніви в чиїйсь любові, вірності. У словнику Д. Н. Ушинського ревнощі визначаються як бажання безроздільно володіти чимось, боязнь чужого успіху, побоювання, що інший зробить краще. Отже, ревнощі це підозріле ставлення людини до об'єкта обожнювання, пов'язане із сумнівами в його вірності, чи інформацією про його невірність. Ф. Ларошфуко писав: "Ревнощі підкріплюються сумнівами; вони вмирають, як тільки сумніви перетворюються у впевненість" [2, с.7].

Ревнощі здатні проникати практично в усі види відносин людей. Ми говоримо про ревнощі дитячі, професійні, національні, спортивні, творчі. М. Фрідман у книзі "Психологія ревнощів" виділяв два різновиди почуття ревнощів: ревнощі любовні та ревнощі в досягненні цілі (у процесі діяльності, у галузі життєвого покликання). Причому перші трапляються частіше, оскільки 3 ними стикаються практично всі подружжя й закохані пари. За визначенням науковця, ревнощі - почуття, що проявляється при змаганні або при безпосередній участі певної особи в діяльності, пов'язаній із сильними переживаннями. Вони виражаються у вигляді хворобливого роздратування, до якого приєднується бажання відтіснити суперника. Ревнощі діють, зазвичай, там, де існують ідеальні чисті цінності почуття, де відіграють роль честь, положення в суспільстві, почесті, гордість, а головне - любов. Інші вчені виділяли ревнощі соціальні й еротичні. При цьому, визнаючи в деяких випадках соціальні ревнощі цінними та корисними, любовні ревнощі вважали негативним явищем, пов'язаним із підозрами й недовірою [5; с.31].

Досліджуючи еротичні (любовні, сексуальні) ревнощі, ми визначили їх як комплекс переживань при дійсній чи підозрюваній зраді коханої людини, що характеризується складною психологічною структурою: типовими й дуже різноманітними емоційними реакціями та станами (заздрість, ненависть, тривога, гнів, відчай, жага помсти, пристрасть й ін.), сумнівами та підозрами, складними проявами в інтелектуальній, вольовій сферах, багатоманітністю форм поведінки, часто соціально небезпечної. За спостереженнями багатьох дослідників, ревнощі досягають особливо різкої вираженості не в молодих подружніх парах, а в тих, які вже давно одружені, тобто тоді, коли поряд із любов'ю (романтичною й сексуальною), моральноетичними, естетичними та іншими факторами набувають значення й такі, які можна віднести до 
базису сім'ї (матеріально-економічні чинники, діти), коли в процесі сімейного життя на зміну закоханості приходить глибоке почуття взаємної прив'язаності, звикання.

У будь-якому випадку любовні ревнощі слід розглядати не як самостійний феномен, а як компонент кохання, який передбачає прагнення до єдності сексуального володіння й духовної спільності з коханими. Ревнощі можуть супроводжувати різні стани кохання: вони можуть бути пов'язаними 3 невпевненістю в любові, брехнею в ній, ії втратою, побоюванням утрати. Такі ревнощі відчуваються особливо гостро.

Усвідомлення своєї самотності й внутрішньої спустошеності супроводжується розчаруванням, сумом, образою, соромом, гнівом. У подібному стані людина не здатна поводити себе раціонально. Ревнощі переслідують її повсюди.

Ревнощі можуть проявлятися на різних фазах кохання: під час його розвитку, пишного розквіту й неминучого старіння. Перша починається з того, що людина створює собі уявний ідеал коханого, шукає його, та закінчується суто платонічною любов'ю до особи, схожої на її прекрасний ідеал. У цей час людина пов'язує свій ідеал із реальним образом. У багатьох почуття ревнощів формується вже на цьому етапі, у юнацькому віці. Потім розвивається друга фаза - фаза пристрасті й палких почуттів, прояву статевого потягу та володіння. Кожен із двох закоханих претендує на іншого. Тут якраз і створюються сприятливі умови й можливості для виникнення та розквіту різноманітних проявів ревнощів. Через місяці або інколи роки бурхлива, палка пристрасть неминуче втрачає свою попередню силу навіть у щасливих союзах. Кохання виявляється в третій фазі свого розвитку. Почугтя стають більш спокійними, суттєвими й переростають у родинні. Ревнощі на цьому етапі рідко виникають уперше, а якщо вони були, то їх сила зменшується. Значно рідше вони залишаються такими ж яскраво вираженими, як і в молодості. Більше того, у випадках, коли один з партнерів ревнивий, кохання довше залишається ніби по-молодому гарячим, таким, що постійно боїться суперництва, боротьби.

Ревнощі не зважають на логіку, здоровий глузд, а інколи навіть і на вимоги закону. Відомі випадки ревнощів до того, кого вже немає в живих чи хто буде, можливо, зустрінутий у майбутньому; ревнощі у зв'язку з наклепом, які не рахуються ні з безмежною до цього вірою партнеру, ні 3 його бездоганною поведінкою. Поставши як явище на межі виникнення моногамної сім'ї, переживши вплив соціально-психологічних, релігійних, етнічних (культурних) факторів, ревнощі продовжують "традиційно" й ретроспективно відображати ці впливи, підтвердженням чого служать постійність, незмінність проявів ревнощів протягом багатьох віків. Існують також так звані "ретроспективні" ревнощі, чи "ревнощі до минулого" коханої людини, зазвичай властиві чоловікам.

Походження ревнощів найчастіше пов'язують із закоренілим у ході історичного розвитку суспільства панівним положенням чоловіка в сім'ї, матеріальною й іншою залежністю дружини від чоловіка, суворим переслідуванням подружньої невірності жінки. Багатовікове безправне положення жінки породило погляд на неї як на річ, власність, що не керує власною волею. Релігійні погляди на жінку сприяли посиленню ії залежності від чоловіка, іiі соціальній i моральній безправності. Представляють інтерес приклади І. Кноблохової, Ф. Кноблохова (1966) про положення жінки в патріархальній селянській сім'ї, де головним був батько. Глава сім'ї мав владу над дружиною й дітьми як організатор робіт, господар власності, диктатор і охоронець норм поведінки та функцій членів сім'ї і як особа, котра карала за проступки. Одним із найтяжчих проступків вважалася подружня невірність дружини, покарання було найсуворішим. Моральні норми чоловіка й жінки в суспільстві значно розійшлись. Чоловіки набули неформального права на легковажні вчинки та захоплення. Поведінка жінки завжди оцінювалася значно суворіше [8, с.1].

Закріпившись у соціально-психологічних, релігійних й етнічних сферах суспільного життя, погляд на ревнощі постійно видозмінювався, але характер проявів ревнощів залишився таким самим. Незважаючи на те, що в житті сучасної сім'ї послабилися привілеї чоловіка, ревнощі проявляються так само, як і в минулі віки. Сімдесят років назад у Радянському Союзі вважали, що підстави для ревнощів у державі повинні зникнути, що ревнощі - це «низьке почуття», «відразливий пережиток минулого», «буржуазне явище». I все ж ревнощі не зникли. Вони так само більше поширені серед чоловіків, як і колись, спостерігаються вкрай тяжкі їх наслідки. Суспільна думка співчуває ревнивцям, і навіть закон вважає ревнощі «пом'якшуючою обставиною» у випадку важких злочинів проти особистості.

А. Н. Волкова реакції ревнощів класифікує за певними критеріями: за критерієм норми - нормальні й патологічні; змісту - афективні, когнітивні, поведінкові; за типом переживання активніша пасивні; за інтенсивністю - помірні й глибокі, тяжкі. 
Нормальні, непатологічні реакції відрізняються адекватністю ситуації, зрозумілі багатьом людям, підзвітні їм, нерідко контрольовані людиною.

Патологічні ревнощі мають протилежні характеристики.

Когнітивні реакції виражаються в прагненні аналізувати факт зради, шукати ії причину, винного (я - партнер - суперник), вибудовувати прогноз ситуації, прослідковувати передісторію, тобто створювати картину події. Когнітивні реакції більше виражені в осіб астенічного складу, інтелектуалів.

Афективні реакції проявляються в емоційному переживанні зради. Найбільш характерні емоції - відчай, гнів, ненависть і презирство до себе й партнера, любов та надія. Залежно від типу особистості афективні реакції протікають на фоні меланхолічної депресії чи гнівної агресії. Переважання афективних реакцій спостерігається в людей художнього, істероїдного, емоційно-лабільного складу.

Поведінкові реакції виступають, як зауважує А. Волкова, у вигляді боротьби чи відмови. Боротьба виражається в спробах відтворити відносини (пояснення), утримати партнера (прохання, переконування, погрози, тиск, шантаж), усунути суперника, ускладнити зустрічі $з$ ним, привернути увагу до себе (викликання жалю, співчуття, іноді - кокетство). При відмові відтворити відносини зв'язок із партнером переривається чи набуває дистанційного, офіційного характеру.

При активних реакціях, характерних для стенічних й екстравертованих особистостей, людина шукає потрібну інформацію, відкрито виражає свої почуття, прагне повернути партнера, змагається із суперником. При пасивних реакціях астенічні та інтровертовані особистості не здійснюють наполегливих спроб повпливати на відносини, ревнощі протікають усередині людини [1, с.75].

Гострі й глибокі реакції ревнощів - результат повної раптовості зради на фоні благополучного шлюбу. Зрада більше ранить довірливу та вірну людину. Ревнощі стають затяжними, якщо ситуація не вирішується, партнер веде себе суперечливо, не приймаючи жодного рішення. Заслуговують на увагу погляди К. Леонгарда стосовно нормальних й патологічних ревнощів. Вчений виділяє дві форми нормальних ревнощів: а) ревнощі, безпечні у своїй основі, що виходять 3 об'єктивно доведеного сексуального регресу; б) ревнощі, що становлять велику соціальну небезпеку, - у формі підозр. У вищих стражданнях ревнощів людина перебуває у великій напрузі, оскільки не може відгородити себе від зради, і тільки тоді, коли стає очевидним, що надія на любов повністю втрачена, у неї залишається лише біль чи ненависть без напруги. Глибока любов, як вважає К. Леонгард, робить людину сліпою: кожна хороша риса, відкрита в коханій людині, приєднується до почуття любові, кожна погана відкидається. Однак існує така сліпота й при негативному чуттєвому стані, наприклад при ревнощах, коли втрачається раціональне в результаті сильного афекту ненависті.

Від специфіки характеру подружжя залежить не тільки різноманітність проявів почуття ревнощів, але й сам процес їх розвитку. Узявши початок від незрозумілих сумнівів (спровокованих початковою установкою чи жартами оточуючих), ревнощі поступово роблять людину все більш підозрілою. Далі появляється чітке уявлення про можливу зраду. Потім ідуть пошуки доказів невірності. Після цього настає переконання в зраді, яке у всіх проявляється порізному: одному для кінцевого висновку достатньо дуже не визначених малодостовірних підстав, а інший, володіючи очевидними фактами, може посилено підшукувати для них якісь виправдання чи інші пояснення й ухилятися від висновку. Залежно від глибини та тривалості переживання, людина або звільняється від ревнощів, розриваючи відносини, або ревнощі тимчасово стихають, щоб потім виникнути зі ще більшою силою й, у результаті, стати хронічними, патологічними.

Стосовно таких хворобливих ревнощів, то вони можуть бути як симптомом психічного захворювання, так і продовженням початкової нормальної емоційної реакції, яка в подальшому проходить указаний вище шлях розвитку та стає цілком домінуючим переживанням, відділеним від почуття кохання. Найчастіше подібна захопленість ревнощами відбувається 3 людьми, котрі мають у характері різноманітні відхилення. Ревнощі охоплюють, крім емоційної, інтелектуальну сферу особистості: порушуються логіка мислення, тимчасові зв'язки теперішнього, минулого й майбутнього, страждає воля, порушується правильне сприйняття того, що відбувається.

Поведінка ревнуючого часто викликає в «обвинуваченого» не ту реакцію, на яку він розраховував, вона викликає почуття страху, страждання, неприязні, нервові розлади, провокує іншого на брехню, помсту, зраду, розлучення. Життя 3 такою людиною може виявитися 
нестерпним для іншого партнера, відбитися на вихованні й здоров'ї дітей, стати мотивом для злочину проти особистості того, кого ревнують, чи суперника, і навіть випадкової людини [2, с. 77].

I патологічні ревнощі, i ревнощі здорової людини загострюються під впливом алкоголю. Учені давно помітили, що любителі спиртного ревнують частіше й сильніше за інших. Звичайно, сам по собі алкоголь ревнощів не створює. Але, як відзначають дослідники, він підштовхує людину до відповідних підозр і розпущеності в поведінці, одночасно викликаючи у взаєминах подружжя ускладнення, які часто дають підстави для сумнівів. Алкоголь тимчасово посилює статевий потяг, але поступово знижує потенцію, що одразу відображається на сексуальних відносинах подружжя, а, відповідно, і на гармонії подружніх відносин у цілому. І тоді як наслідок для ревнивця - або лікування, або розлучення, або повна деградація особистості, а можливо й скоєння злочину [5, с.66].

Як безпосередньо почуття ревнощів, так і поведінка ревнивця можуть спровокувати конфліктні відносини між подружжям. Недовіра, підозри, грубість, принизливі перевірки несумісні з любов'ю, ображають особисту гідність і взаємну повагу люблячих, заздалегідь передбачають брехню та зраду партнера. Часто брехня й зрада як засоби самозахисту людини $\epsilon$ продуктами ревнощів. Спроби викриття неправди породжують нову брехню. Безкінечні нотації, докори та скандали роблять людині нестерпним перебування вдома, заважають проаналізувати сімейні проблеми й сприяють намаганню шукати втіхи десь на стороні.

Задля реалізації поставленої мети, ми провели експериментальне дослідження, яке включало в себе опитування 46 респондентів - студентів Хмельницького національного університету, які перебувають у подружніх взаєминах. Для діагностики була застосована методика «семантичний диференціал», тест для діагностики ревнощів.

В ході проведеного дослідження, зокрема виходячи 3 даних анкети, ми прийшли до висновку, що більша частина молодих людей незалежно від статі вважає, що зрада це сексуальний контакт «на стороні», а найбільш частою реакцією у чоловіків був розрив відносин, у жінок - агресія або істерика. При цьому, вивчаючи результати проведеного опитування, ми виділили такі цікаві закономірності:

- респонденти чоловічої статі у віці 20-21 років схильні пробачити своєму партнеру зраду частіше, ніж більш старші люди, в той час як серед дівчат здатні пробачити зустрілися в діапазоні 22-25 років;

- однієї з найбільш вагомих причин зради $є$ незадоволеність партнером, її виділяють більшість опитаних обох статей;

- відносини 3 представниками своєї статі більшість молодих людей вважає зрадою, причому чоловіки частіше (і сприймають подібну можливість негативніше), ніж дівчата.

Методика «Семантичний диференціал» так само дала досить великий матеріал для аналізу. В ході обробки даних ми отримали наступні результати:

За параметром Я: рівень оцінки себе у студентів лежить в межах середнього значення, що вказує на те, що вони задоволені власною поведінкою, рівнем досягнень, позитинво сприймають самих себе.

Дівчата показують трохи завищені результати, тобто схильні усвідомлювати себе як носієм позитивних, соціально-бажаних характеристик, так і визнавати наявність недоліків в самих собі; оцінка сили по параметру Я у жінок більше, ніж у чоловіків - це свідчить про те, що свої вольові якості особистості жінки оцінюють вище, ніж чоловіки, вони впевнені в собі; значення знаходиться в межах середнього, що говорить про схильність розраховувати на власні сили; фактор активності у дівчат вище, ніж у хлопців, що свідчить про більш високу екстравертованість жінок. Це також доводиться результатами анкети. Результати знаходяться в межах середнього значення, що вказує на товариськість, імпульсивність, які проявляються в залежності від ситуації.

За параметром Партнер фактор оцінки у жінок трохи вище, ніж у чоловіків, що може свідчити про більшу перевагу партнера, про його більшу привабливість, симпатію, якою він володіє в сприйнятті дівчат;

фактор сили вказує на те, що в суб'єктивному уявленні жінок, вони можуть перебувати в підлеглому положенні від чоловіків;

фактор активності показує, що чоловіки сприймають партнерок як більш відкриту складову пари.

За параметром Зрада: у представників обох статей за критерієм «Оцінки» результати приблизно однакові і знаходяться близько нижніх меж, що говорить про іï заперечення i відторгнення; 
фактор Сили у жінок трохи нижче, що може вказувати на недостатній рівень самоконтролю, а також залежність від зовнішніх обставин.

Фактор Активності вище представлений у чоловіків, що говорить про сприйняття респондентами даного поняття як пов'язаного 3 особистими особливостями партнерів, що відносяться не тільки безпосередньо до них.

Висновком 3 обробки результатів тесту на діагностику ревнощів стало те, що велика частина опитаних респондентів, як жіночої, так і чоловічої статі, $є$ ревнивими, але не агресивними - їх результати лежать в діапазоні від 22 до 27 балів. Що, однак, розходиться 3 даними анкет, в яких, принаймні жінки, показують агресивну реакцію в ситуації зради. Це може бути пов'язано з фактором соціальної бажаності, або більш високою емоційністю жінок це також підтверджується даними анкети. Необхідно також відзначити, що юнаки, в свою чергу, показали більш високий рівень ревнощів, що може бути пов'язано 3 бажанням домінувати у відносинах. В той же час протилежну тенденцію (байдужість або повна довіра партнеру) чоловіки демонструють частіше.

Висновки. У проведеному дослідженні ми отримали результати, що дозволили зробити наступні висновки.

1. Уявлення студентів про ревнощі $є$ суб'єктивним вираженням їх обізнаності про сутність ревнощів, підстави їх виникнення, стан та перспективи розвитку подружніх відносин, пройнятих почуттям ревнощів.

2. Розуміння студентів про подружні ревнощі полідетермінується об'єктивними і суб'єктивними факторами. До об'єктивних чинників розвитку уявлень студентів про подружні ревнощі відносяться статева приналежність, досвід подружнього життя і досвід спостереження ревнощів у відносинах батьків. До суб'єктивних факторів розвитку уявлень респондентів про подружні ревнощі відносяться особливості їх емоційної і ціннісної сфер особистості.

3. Розвиток уявлень студентів про подружні ревнощі характеризується розширенням їх обізнаності про причини і наслідки виникнення ревнощів у відносинах подружжя і зміцненням причинно-наслідкових зв'язків між даними структурними компонентами. Станом сформованості уявлень про подружні ревнощів студенти ВНЗ можуть бути диференційовані на три групи: студенти зі сформованими, змішаними та ілюзорними уявленнями про ревнощі.

4. Студенти незалежно від стану сформованості їх уявлень про ревнощі з більшою або меншою конкретністю відзначають, що ревнощі завжди супроводжується певними порушеннями комунікативної сфери подружжя: виникає особистісна тривожність, знижується рівень взаємної довіри, виникають конфлікти. З'ясування відносин між членами подружжя протікає з високим рівнем конфліктності і агресивності. Невміння залучити продуктивні стратегії поведінки в конфлікті призводить до їх затягування i остаточного руйнування подружніх стосунків.

5. Формування уявлень студентів ВНЗ про ревнощі дає позитивні результати в сфері їх подружніх відносин, якщо грунтуватися на розширенні у них інформованості про психологію сімейного життя та міжособистісних відносин в поєднанні з розвитком якостей, що сприяють побудові гармонійних подружніх відносин.

6. Формування уявлень студентів про подружні ревнощі на основі спеціально розробленої комплексної програми, яка передбачає теоретичні i практичні аспекти побудови подружніх відносин, знижує ймовірність виникнення проявів ревнощів в реальному житті студентів.

Отже, підводячи підсумки нашого дослідження, зазначимо, що воно являє собою лише один 3 можливих варіантів вивчення широкого поля проблематики ревнощів, в цілому, i подружніх ревнощів, зокрема. Обраний нами ракурс звернення до суб'єктивного відбиття подружніх ревнощів в уявленнях респондентів - студентських сімей - дозволив отримати психологічні дані про те, яким чином ревнощі формується до початкового періоду молодості людини, коли він тільки набуває самостійності і отримує можливість вибудовувати свої подружні стосунки. Очевидно, що робота в даному напрямку може бути продовжена 3 використанням інших дослідницьких ракурсів, 3 залученням інших дослідницьких методів i методик, іншої дослідницької вибірки.

Таким чином, проаналізувавши позитивну та негативну роль ревнощів у взаєминах, можна стверджувати, що для багатьох людей ревнощі - один із приємних доказів любові, i сприймаються вони ними - у певних дозах - iз задоволенням. Ці природні ревнощі відіграють активізуючу роль у коханні. «Ніщо так не прив'язує, як ревнощі», - пише Андре Моруа.

Ревнощі, залишаючись на високоморальних позиціях, не ведуть до підозрілості, образ, підглядання, взаємної ненависті, не створюють атмосфери недовіри до об'єкта своїх почуттів і 
хвилювань. Вони викликають смуток про втрачені хвилини спілкування, тугу за можливою втратою коханої людини. Любовні задоволення, на думку філософів, потребують певного стимулятора. Вони ніколи не можуть довго існувати «безхмарно». Ось чому, на їхню думку, коханню необхідний легкий напад суму, трохи ревнощів, сумнівів, драматичної гри [1].

Проте ревнощі можуть ставати цілком домінуючим переживанням, відділеним від почуття любові, здатні стати нав'язливими, навіть ілюзорним страхом, що може викликатися будь-якими чинниками. Ревнощі охоплюють, крім емоційної, інтелектуальну сферу особистості - порушуються логіка, мислення, часові зв'язки теперішнього, минулого й майбутнього, страждає воля, порушується правильне сприйняття того, що відбувається. Поведінка ревнуючого часто викликає «в обвинуваченого» не ту реакцію, на яку він розраховував, викликає почуття страху, страждання, неприязні, нервові розлади, провокує іншого на брехню, помсту, зраду, розлучення. Життя з такою людиною може виявитися нестерпним для іншого партнера, зіпсувати психічне й фізичне здоров'я, відобразитися на вихованні та здоров'ї дітей, стати мотивом злочину проти особистості того, кого ревнують, чи суперника, або навіть випадкової людини.

Заради уникнення у відносинах почуття ревнощів потрібно із самого початку сімейного життя створити таку атмосферу в сім'ї, щоб не було місця докорам, приниженням, суперечкам, щоб кожен із подружжя міг відчути свою необхідність й особливу значимість у сім'ї. Створення благополучного психологічного клімату, основаного на взаємній довірі та взаємній відвертості, взаєморозумінні й взаємній повазі, сімейного клімату, що дало б змогу кожному відчути свою цінність і потрібність для іншого, залишаючись при цьому самим собою, - це найкращий захист від усіляких спокус, брехні, сумнівів та недовіри.

\section{ЛІТЕРАТУРА}

1. Андреева Т. В. Семейная психология / Учеб. пособие / Т. В. Андреева. - СПб.: Речь, 2004. - 244 с.

2. Доценко Е.Л. Манипуляция: психологическое определение понятия // Психол. журн. / Е. Л. Доценко. - 2003. - Т.14. - № 4.

3. Камерон-Бэндлер Л. С тех пор они жили долго и счастливо: простая и эффективная психотерапия сексуальных проблем и трудностей во взаимоотношениях / Л. Ккамерон-Бэндлер. - Воронеж: НПО «МОДЭК», 2003. - $187 \mathrm{c.}$

4. Капустин С.А. Границы возможностей психологического консультирования // Вопросы психологии / С. А. Капустин. - 2008. - № 5. - С.12.

5. Кристенсен Т. Модель решения проблемы // Вестник РАТЭПП / Т. Кристенсен. - 2013. - № 1-2.

6. Линчевский Э.Э. Как быть с ревностью / Э.Э Линчевский. - Л.,»Знание», 2008. - 36 с.

7. Меновщиков В.Ю. Введение в психологическое консультирование / В. Ю. Меновщиков. - М.: Смысл, 2009. - 327 с.

8. Столин В. В. Семья в психологической консультации: Опыт и проблемы психологического консультирования / Под ред. А.А. Бодалева, В.В Столина. М.: Педагогика, 2009. - 412 с.

9. Фельдштейн Д.И. Психология становления личности / Д. И. Фельдштейн. - М.: Международная педагогическая академия, 2004. - 298 с.

10. Цапкин В.Н. Единство и многообразие психотерапевтического опыта // Моск. психотерапевт. Журнал / В. Н. Цапкин. - 2002. - № 2. - с. 16.

11. Эксакусто Т.В. Психодиагностика. Коллекция лучших тестов / Т. В Эксакусто. - Р-нД.» Феникс», 2010. $-374 \mathrm{c}$. 